\title{
B2M Gene
}

National Cancer Institute

\section{Source}

National Cancer Institute. B2M Gene. NCI Thesaurus. Code C62660.

This gene plays a role in immune responses. 